\title{
Methacholine challenge testing: comparative pharmacology
}

\author{
Beth E Davis \\ Christianne M Blais \\ Donald W Cockcroft \\ Division of Respirology, Critical Care \\ and Sleep Medicine, Department of \\ Medicine, University of Saskatchewan, \\ Saskatoon, SK, Canada
}

This article was published in the following Dove Press journal: Journal of Asthma and Allergy
Correspondence: Beth E Davis Department of Medicine, University of Saskatchewan, 103 Hospital Drive, Saskatoon, SK S7N 0W8, Canada

$\mathrm{Tel}+$ I 306844 I444

Fax +I 306844 I532

Email beth.davis@usask.ca

\begin{abstract}
Standardization of the methacholine inhalation challenge, the most common direct bronchoprovocation test, is important. One aspect of standardization is the appropriate washout period for pharmacologic agents which affect the response. This review summarizes the available data on pharmacologic inhibition of the methacholine response. Specific (anti-muscarinic) agents demonstrate marked bronchoprotection (up to 7 days for the long-acting drugs) which lasts longer than the duration of bronchodilation. The functional antagonist (beta 2 agonist class of medications) shows marked, but less, bronchoprotection which is relatively short lived and is similar to the duration of bronchodilator efficacy. Tolerance develops quickly, especially to the long-acting agents. Single doses of controller medications, such as inhaled corticosteroids (ICS) and leukotriene receptor antagonists, have no effect on the methacholine test, while regular use, at least for ICS, has a modest protective effect whose duration is uncertain and likely variable. Theophylline has a small effect and $\mathrm{H} 1$ blockers (all generations) have a negligible effect. Keywords: methacholine challenge, bronchoprotection, muscarinic antagonist, beta agonist, glucocorticosteroid, antihistamine
\end{abstract}

\section{Introduction}

The methacholine inhalation challenge test is widely used both in clinical and in research settings to measure direct airway responsiveness. ${ }^{1}$ The results are traditionally expressed as the provocation dose (PD) or concentration (PC) that results in a $20 \%$ fall in the forced expiratory volume in 1 second $\left(\mathrm{FEV}_{1}\right)$, the $\mathrm{PD}_{20}$ or $\mathrm{PC}_{20}$. The $\mathrm{PD}_{20}$ has short-term repeatability of $\pm 1-1.5$ doubling doses, mostly due to lack of precision rather than genuine variation. Adequate standardization of the test is therefore important to assure the best discrimination between normal and increased responsiveness and to compare results between different methods. Standardization documents have been produced by the American Thoracic Society ${ }^{2}$ and more recently updated by the European Respiratory Society. ${ }^{3}$ One important aspect of standardization is the withhold time for various respiratory and non-respiratory medications which may affect the test. We found that in preparing both the 2000 and 2017 documents, data regarding this were frequently lacking or at best incomplete. This prompted several of our own investigations as well as this review article.

Airway hyper-responsiveness (AHR) to methacholine is defined as an increase in sensitivity (left shift of the dose-response curve, ie, $\mathrm{PD}_{20} / \mathrm{PC}_{20}$ ), reactivity (slope of the curve), and/or increase and eventual loss of the maximal dose-response plateau. ${ }^{4}$ AHR is a characteristic feature of asthma. Clinically, the methacholine challenge test (MCT) is highly sensitive with a high negative predictive value and is particularly useful submit your manuscript Dovepress if in $D$ http://dx.doi.org/10.2147/JAA.S160607 
to exclude a diagnosis of "current" asthma when the test is negative. ${ }^{1-3}$ In research, the MCT is used to identify eligible study participants, assess changes in AHR following allergen exposure, or determine the bronchoprotective effect of novel compounds. Methacholine challenge testing has also been used to investigate therapeutic bioequivalence ${ }^{5}$ and may have a role in the evaluation and management of severe asthma. ${ }^{6}$ Pharmacological agents will inhibit or suppress the response to methacholine by specific antagonism (eg, anti-muscarinic agents), by functional antagonism (eg, other bronchodilators, especially beta agonists), or by an anti-inflammatory effect (eg, corticosteroids). Potentially, any/all aspects of the methacholine response may be affected; however, the large majority of studies address the $\mathrm{PD}_{20} / \mathrm{PC}_{20}$ (sensitivity). The purpose of this communication is to provide a reference for the comparative pharmacology of various respiratory medications on (primarily clinical) methacholine challenge testing.

\section{Bronchodilators}

\section{Muscarinic antagonists - short acting}

Inhaled methacholine induces bronchoconstriction in a manner analogous to that of acetylcholine. Methacholine binds airway smooth muscle (ASM) muscarinic receptors, importantly the $\mathrm{M}_{3}$ subtype triggering a cascade of intracellular signals that ultimately leads to the release of calcium and ASM contraction. The result is a decrease in airway diameter and an increase in resistance to airflow that can be quantitated by simple spirometry. Anticholinergic agents or muscarinic antagonists inhibit this response. The use of atropine-containing cigarettes for treating bronchospasm was an early indication of anticholinergic efficacy. ${ }^{7}$ Other early investigations using more controlled methodology, although not as refined as that used today, also showed the effectiveness of atropine. ${ }^{8-10}$ Ipratropium bromide (IB; formerly SCH1000), developed in the early 1970s, was the first modern inhaled muscarinic receptor antagonist for relieving bronchoconstriction. Each actuation of the pressurized metered dose inhaler (pMDI) device delivers a $20 \mu \mathrm{g}$ dose. The standard dose is $40 \mu \mathrm{g}$ as needed. The bronchoprotective effects of IB against inhaled methacholine have varied with respect to mode of administration, dose, time point of measurement, and end point (Table 1). Following a standard dose of IB via pMDI, an average of 2.5 doubling concentration protection from methacholine-induced bronchoconstriction (MIB) has been shown at 20 and 60 minutes post-dose. ${ }^{11,12}$ An earlier study in nine asthmatic children using twice the standard dose $(80 \mu \mathrm{g})$ of SCH1000 via pMDI showed complete inhibition of the response (i.e, flat dose-response curve) at 30 minutes post-dose. The limitations on quantifying the response were twofold: first, the maximum concentration of methacholine used was $25 \mathrm{mg} / \mathrm{mL}$ and second, participants had, on average, relatively mild baseline airway responsiveness (mean methacholine $\mathrm{PD}_{20}$ [provocative dose causing a $20 \%$ fall in forced expiratory volume] of $13.9 \mu \mathrm{g}$ ) at baseline. ${ }^{13}$ A subsequent study used concentrations of methacholine up to $362 \mathrm{mg} / \mathrm{mL}$. In this adult population, the mean shift in methacholine $\mathrm{PC}_{20}$

Table I Bronchodiltor: SAMAs

\begin{tabular}{|c|c|c|c|c|c|c|}
\hline Agent & Device & $\begin{array}{l}\text { Dose } \\
(\mu g)\end{array}$ & $\begin{array}{l}\text { End } \\
\text { point }\end{array}$ & $\begin{array}{l}\text { Time } \\
\text { point } \\
\text { (hours) }\end{array}$ & $\begin{array}{l}\text { Dose shift } \\
\text { (doubling } \\
\text { concentrations) }\end{array}$ & Reference (year) \\
\hline Ipratropium & pMDI & 80 & $\mathrm{PD}_{20}$ & 0.5 & NQ & Woenne et $\mathrm{al}^{13}(1978)$ \\
\hline Ipratropium & pMDI & 80 & $\mathrm{PC}_{20}$ & I & 5.8 & Bandouvakis et al ${ }^{14}(|98|)$ \\
\hline Ipratropium & pMDI and DPI & 80 & sGaw & 0.75 & $\sim 4$ & Larsson $^{15}(1987)$ \\
\hline Ipratropium & pMDI & 200 & sGaw & 0.75 & 4 & Larsson $^{15}(1987)$ \\
\hline Ipratropium & DPI & 200 & sGaw & 0.75 & 5 & Larsson $^{15}(1987)$ \\
\hline Ipratropium & pMDI & 40 & $\mathrm{PD}_{20}$ & 0.33 & 2.3 & Crimi et al" (1992) \\
\hline \multirow[t]{4}{*}{ Ipratropium } & DeVilbiss & 500 & $\mathrm{PC}_{20}$ & 2 & 5 & Hansel et $\mathrm{al}^{16}$ \\
\hline & \multirow[t]{3}{*}{700 Nebulizer } & & & 12 & 0 & \multirow[t]{3}{*}{ (2005) } \\
\hline & & & & 24 & 0 & \\
\hline & & & & 30 & 0 & \\
\hline Ipratropium & pMDI & 40 & $\mathrm{PD}_{15}$ & 1 & 2.7 & $\begin{array}{l}\text { Sposato et } \mathrm{al}^{12} \\
(2008)\end{array}$ \\
\hline Ipratropium & Nasal spray & $\begin{array}{l}0.03 \% \\
(2 / \text { nare })\end{array}$ & $\mathrm{PC}_{20}$ & 0.16 & $<0.5$ & $\begin{array}{l}\text { Reid et al }{ }^{19} \\
(2005)\end{array}$ \\
\hline \multirow[t]{2}{*}{ Ipratropium } & \multirow[t]{2}{*}{ pMDI } & \multirow[t]{2}{*}{40} & \multirow[t]{2}{*}{$\mathrm{PC}_{20}$} & 6 & 1 & \multirow[t]{2}{*}{ Illamperuma et al ${ }^{18}$ (2009) } \\
\hline & & & & 12 & $<0.5$ & \\
\hline Oxitropium & pMDI & 200 & $\mathrm{PD}_{15}$ & 1 & 4.2 & Sposato et al' ${ }^{12}(2008)$ \\
\hline
\end{tabular}

Abbreviations: SAMAs, short-acting muscarinic antagonists; PMDI, pressurized metered dose inhaler; DPI, dry powder inhaler; $\mathrm{PD}_{20}$, provocation dose that results in a $20 \%$ fall in the forced expiratory volume in I second; $\mathrm{PC}_{20}$, provocation concentration that results in a $20 \%$ fall in the forced expiratory volume in I second; sGaw, airway conductance; $\mathrm{PD}_{15}$, dose of methacholine producing a $15 \%$ decrease in forced expiratory volume in I second; NQ, not quantifiable. 
(provocative concentration causing a 20\% fall in forced expiratory volume) was 5.8 doubling concentrations at 60 minutes following pMDI inhalation of $80 \mu \mathrm{g}$ of IB. ${ }^{14}$ Larsson et al investigated bronchoprotection 45 minutes after 80 or 200 $\mu \mathrm{g}$ IB administered via pMDI or dry powder inhaler (DPI). ${ }^{15}$ Using a $35 \%$ reduction in specific airway conductance (sGaw $\mathrm{PC}_{35}$ ) as the end point, they showed similar effects on airway sensitivity to methacholine (4-5 doubling concentrations) that were independent of dose and device. The protection afforded by $500 \mu \mathrm{g}$ of nebulized IB and assessed at 2 hours post-dose ${ }^{16}$ was similar to that shown by Larsson. Although the exact magnitude of bronchoprotection following a 500 $\mu \mathrm{g}$ dose of nebulized atropine could not be quantified (low threshold concentration of $16 \mathrm{mg} / \mathrm{mL}$ ), a minimum shift of 5-6 doubling concentrations has been observed; this shift is about 3-4 doubling concentrations greater than that following the same dose administered intravenously. ${ }^{17}$ On average, the protective effect is diminished to one doubling concentration at 6 hours following a standard dose. ${ }^{18}$ Half of those studied at 6 hours showed greater than the average protection and none showed significant protection at 12 hours post-dose. Bronchoprotection following nebulized high dose is also negligible by 12 hours. ${ }^{16}$ Nasal administration of a $0.3 \%$ solution showed a slight statistically significant but clinically irrelevant inhibitory effect on the MCT 10 minutes after dosing. ${ }^{19}$ Another shortacting muscarinic antagonist (SAMA) is oxitropium bromide (OB). At five times the standard dose of IB, OB produces roughly 1.5 times the bronchoprotection against MIB 1 hour after dosing (OB 4.2 vs IB 2.7 doubling concentrations). ${ }^{12}$ The SAMA data are summarized in Table 1.

\section{Muscarinic antagonists - long acting}

Long-acting muscarinic antagonists (LAMAs) include tiotropium (TIO), glycopyrronium, aclidinium, and umeclidinium. Classification based on duration of action relates to the bronchodilator property of these agents. This is reflected in the dosing regimen and determined through the clinical development process. TIO, for example, is dosed once per day (ie, bronchodilator effects last $>24$ hours). On the other hand, bronchodilation following IB is on the order of 6 hours and dosing can be 3-4 times per day. As indicated earlier, protection against MIB following a standard dose of IB is reduced at 6 hours and therefore consistent with the duration of bronchodilation. This does not appear to be the case with LAMAs where bronchodilation is short-lived relative to the bronchoprotective property. O'Connor et al studied three doses of TIO $(10,40$, and $80 \mu \mathrm{g})$ vs placebo in random order with each delivered as a single dose via the
DPI 2 hours prior to methacholine challenge testing. ${ }^{20}$ Nonlinear dose-dependent bronchoprotection was evident across the dosing range $(5.0,7.1$, and 7.9 doubling concentration shifts for 10,40 , and $80 \mu \mathrm{g}$ respectively). The protection, although decreased to 2.2, 2.2, and 3.0 doubling concentrations, persisted to 48 hours and in a small subpopulation of the study cohort $(n=4)$ was still evident at 72 hours. A mild dose-independent bronchodilator effect was noted but the effect did not surpass 24 hours. TIO delivered via the DPI showed slightly less maximal bronchoprotection (4.1 doubling dose shift) following a single $18 \mu \mathrm{g}$ dose. ${ }^{12}$ This effect has also been observed with a single $5 \mu \mathrm{g}$ dose of TIO delivered via the Respimat ${ }^{\circledR}$ inhaler (Boehringer Ingelheim, Ingelheim am Rhein, Germany; 4.2 doubling concentration shift). ${ }^{21}$ The Blais et al study followed the duration of bronchoprotection to 168 hours (ie, 7 days) and found the effect to be small but still present and statistically significant. This was a comparative study with glycopyrronium (single dose of $50 \mu \mathrm{g}$ via DPI). Glycopyrronium produced similar maximal bronchoprotection to MIB at 1 hour (4.3 doubling concentrations) and significant protection, although comparatively less, at subsequent time points $(24,48,72$, and 96 hours). In contrast to the bronchoprotective effect of TIO at 168 hours, the small protective effect of glycopyrronium observed at 168 hours was not significant. Glycopyrronium bronchoprotection at 1, 24, and 48 hours was reproduced by this same group in a subsequent study. ${ }^{22}$ Neither treatment produced clinically significant bronchodilation, possibly explained by the mild asthma study population.

The bronchoprotective properties of high-dose nebulized racemic glycopyrrolate $(500,1000,2000 \mu \mathrm{g})$ have also been studied. ${ }^{16}$ Maximal protection against MIB was similar to that shown by standard doses administered with the DPI or Respimat. The highest dose produced the least bronchodilation ( $~ 5 \%$ at $1-2$ hours). The two lower doses improved the 1-2 hour post-dose $\mathrm{FEV}_{1}$ by about $10 \%$.

As would be expected, inhaled selective muscarinic antagonists like IB and TIO decrease airway sensitivity to methacholine and, on average, produce a maximal shift in the dose-response curve, about 5 doubling concentrations (ie, about 32-fold) to the right. The maximal effect appears to be independent of both the dose and the delivery device. Although not widely studied, protection against MIB bronchoconstriction following single-dose SAMA is minimal at 12 hours and that following single-dose LAMA lasts 7 days. This difference is presumably explained by the prolonged binding and slow dissociation of the LAMA from the muscarinic receptor. Receptor downregulation may also 
be a consequence of prolonged LAMA/M $\mathrm{M}_{3}$ binding and may contribute to a decrease in the response to inhaled methacholine. The LAMA data are summarized in Table 2.

There are limited data on other aspects of the methacholine dose-response curve. Both TIO and glycopyrronium resulted in the appearance of a plateau response 1 hour after administration. ${ }^{21}$ The mechanism of this finding is uncertain.

\section{Beta agonists - short acting}

Beta agonists prevent ASM contraction through "functional" antagonism. These agents are sympathomimetic and bind ASM adrenergic beta 2 receptors. The beta 2 receptor is a $\mathrm{G}$ protein $\left(\mathrm{G} \alpha_{\mathrm{s}}\right)$ coupled receptor that activates adenylyl cyclase, leading to an increase in the level of intracellular cyclic adenosine monophosphate (cAMP). Cyclic AMP in turn activates protein kinase A, which prevents/reverses ASM contraction by at least two mechanisms: the first is activation of a transmembrane calcium/potassium exchange/channel that decreases the amount of intracellular calcium and the second is inhibition of myosin light chain kinase. Beta agonists used in respiratory illness have also evolved to include both shortand long-acting formulations. Salbutamol (pMDI) and terbutaline (DPI) are commonly used short-acting beta agonists (SABAs). A standard dose of $200 \mu \mathrm{g}$ salbutamol delivered via pMDI shifts the methacholine dose-response curve, on average, about 3.5 doubling concentrations to the right when

Table 2 Bronchodilator: long-acting muscarinic antagonists (including combination LAMA/LABA)

\begin{tabular}{|c|c|c|c|c|c|c|}
\hline Agent & Device & $\begin{array}{l}\text { Dose } \\
(\mu g)\end{array}$ & $\begin{array}{l}\text { End } \\
\text { point }\end{array}$ & $\begin{array}{l}\text { Time point } \\
\text { (hours) }\end{array}$ & $\begin{array}{l}\text { Dose shift } \\
\text { (doubling } \\
\text { concentrations) }\end{array}$ & $\begin{array}{l}\text { Reference } \\
\text { (year) }\end{array}$ \\
\hline \multirow[t]{3}{*}{ Tiotropium } & DPI & 10 & $\mathrm{PC}_{20}$ & 2 & 5.0 & $\mathrm{O}^{\prime}$ Connor et $\mathrm{a}^{20}$ \\
\hline & & 40 & & & 7.1 & $(1996)$ \\
\hline & & 80 & & & 7.9 & \\
\hline Tiotropium & DPI & 18 & $\mathrm{PD}_{15}$ & 1 & 4.1 & $\begin{array}{l}\text { Sposato et al }{ }^{\prime 2} \\
(2008)\end{array}$ \\
\hline \multirow[t]{6}{*}{ Tiotropium } & Respimat & 5 & $\mathrm{PC}_{20}$ & 1 & 4.2 & Blais et $\mathrm{al}^{21}$ \\
\hline & & & & 24 & 3.1 & $(2016)$ \\
\hline & & & & 48 & 2.7 & \\
\hline & & & & 72 & 2.3 & \\
\hline & & & & 96 & 1.9 & \\
\hline & & & & 168 & 0.84 & \\
\hline \multirow[t]{6}{*}{ Glycopyrronium } & DPI & 50 & $\mathrm{PC}_{20}$ & 1 & 4.3 & Blais et $\mathrm{a}^{21}$ \\
\hline & & & & 24 & 1.8 & $(2016)$ \\
\hline & & & & 48 & 1.9 & \\
\hline & & & & 72 & 1.2 & \\
\hline & & & & 96 & I.I & \\
\hline & & & & 168 & 0.52 & \\
\hline \multirow[t]{3}{*}{ Glycopyrronium } & DPI & 50 & $\mathrm{PC}_{20}$ & 1 & 5 & Blais et $\mathrm{a}^{22}$ \\
\hline & & & & 24 & 2 & $(2017)$ \\
\hline & & & & 48 & 2 & \\
\hline Racemic & DeVilbiss & 500 & $\mathrm{PC}_{20}$ & 2 & 4 & Hansel et al ${ }^{16}$ \\
\hline \multirow[t]{3}{*}{ glycopyrrolate } & 700 Nebulizer & & & 12 & 2 & $(2005)$ \\
\hline & & & & 24 & I & \\
\hline & & & & 30 & I & \\
\hline Racemic & DeVilbiss & 1000 & $\mathrm{PC}_{20}$ & 2 & 6 & Hansel et al ${ }^{16}$ \\
\hline \multirow[t]{3}{*}{ glycopyrrolate } & 700 Nebulizer & & & 12 & 4 & $(2005)$ \\
\hline & & & & 24 & 3.5 & \\
\hline & & & & 30 & 3 & \\
\hline Racemic & DeVilbiss & 2000 & $\mathrm{PC}_{20}$ & 2 & 5 & Hansel et $\mathrm{a}^{16}$ \\
\hline \multirow[t]{3}{*}{ glycopyrrolate } & 700 Nebulizer & & & 12 & 3 & $(2005)$ \\
\hline & & & & 24 & 3 & \\
\hline & & & & 30 & 2 & \\
\hline LAMA/LABA & DPI & 50 & $\mathrm{PC}_{20}$ & 1 & 5 & Blais et $\mathrm{a}^{22}$ \\
\hline combination & DPI & 75 & & 24 & 2 & $(2017)$ \\
\hline Glycopyarronium & & & & 48 & 2 & \\
\hline Indacaterol & & & & & & \\
\hline
\end{tabular}

Abbreviations: LAMA, long-acting muscarinic antagonists; LABA, long-acting beta antagonists; DPI, dry powder inhaler; PC $_{20}$, provocation concentration that results in a $20 \%$ fall in the forced expiratory volume in I second; $\mathrm{PD}_{15}$, provocation dose that results in a $15 \%$ fall in the forced expiratory volume in $\mathrm{I}$ second. 
assessed at $10^{23-25}$ or 30 minutes post-dose (range $\left.2.4-4.6\right) .^{26}$ The effect diminishes to 1.9 doubling concentrations at 1 hour ${ }^{27}$ and is absent at 12 hours. ${ }^{26}$ Smaller $(100 \mu \mathrm{g})$ and larger $(400 \mu \mathrm{g})$ doses produce similar inhibition (2.9-4.5 doubling concentrations, respectively). ${ }^{23}$ Large nebulized doses of $\mathrm{R}$ $(1.25 \mathrm{mg})$ and racemic salbutamol $(2.5 \mathrm{mg})$ provide the same protection at 20 minutes as a standard dose delivered via pMDI (3.3 and 3.4 doubling concentrations, respectively). ${ }^{28}$ A high nebulized dose of the $\mathrm{S}$ isomer, although showing some effect ( 0.9 doubling concentrations), contributes little to the overall bronchoprotective effect afforded by the racemic molecule. ${ }^{28}$ When reassessed at 3 hours, the $\mathrm{S}$ isomer was ineffective and the protection produced by both racemic salbutamol and $\mathrm{R}$ salbutamol had decreased to about 1 doubling concentration. A subsequent study using standard doses of racemic $(200 \mu \mathrm{g}), \mathrm{R}(100 \mu \mathrm{g})$, and $\mathrm{S}(100 \mu \mathrm{g})$ delivered via nebulizer confirmed the ineffectiveness of the $\mathrm{S}$ isomer and showed shifts in methacholine $\mathrm{PC}_{20}$ of $\sim 3$ doubling concentrations for both the $\mathrm{R}$ isomer and the racemic molecule. ${ }^{29}$ At 1.5 hours post-dose, bronchoprotection against MIB provided by a standard dose of terbutaline $(500 \mu \mathrm{g})$ via pMDI is similar to that shown with $200 \mu \mathrm{g}$ salbutamol at 1 hour post-dose (ie, $\sim 1.8$ doubling concentration shift). ${ }^{30,31}$ This is about 1 doubling concentration less than that shown at 20 minutes following a single dose of $500 \mu \mathrm{g} .{ }^{32}$ The bronchoprotection afforded by terbutaline is essentially gone by 6 hours. ${ }^{30} \mathrm{Com}-$ parison of maximal bronchoprotection between terbutaline and salbutamol is not possible from currently available data as the effect with terbutaline was not studied at earlier time points. One would anticipate that similar bronchoprotection would be observed. A large dose of fenoterol $(800 \mu \mathrm{g}$ via pMDI, twice the standard dose) produced a 4 doubling concentration shift in methacholine $\mathrm{PC}_{20}$ at 1 hour post-dose. ${ }^{14}$ The SABA data are summarized in Table 3.

\section{Beta agonists - long and ultra long acting}

Long-acting beta agonists (LABAs) include salmeterol and formoterol. The more recently developed ultra-long-acting formulations or uLABAs include indacaterol, olodaterol, and vilanterol. Salmeterol appears to provide a similar magnitude of bronchoprotection as its short-acting counterpart salbutamol but at a much smaller dose and for a longer duration. For example, $50 \mu \mathrm{g}$ salmeterol via pMDI produces a 4 doubling concentration shift in methacholine $\mathrm{PC}_{20}$ at 30 minutes, and this protection is maintained for at least 12 hours. ${ }^{26,33}$ Others have shown a 3.3 doubling concentration shift at 1 hour after $50 \mu \mathrm{g}$ salmeterol. ${ }^{34,35}$ Halving the dose had no effect on the duration of protection but decreased the magnitude of protection by about twofold, from 4 doubling concentrations to 3 doubling concentrations. ${ }^{26}$ Others have shown less bronchoprotection at equal $(50 \mu \mathrm{g})$ and higher $(100 \mu \mathrm{g})$ doses. ${ }^{27}$ A $24 \mu \mathrm{g}$ dose of formoterol, a dry powder formulation, provides comparable bronchoprotection to that seen with salmeterol (ie, 4 doubling doses at 1 hour postdose). ${ }^{5,31,36}$ MIB is inhibited with lower doses (6 and $12 \mu \mathrm{g}$ ), about twofold less than the $24 \mu \mathrm{g}$ dose, and there is little difference in the magnitude of bronchoprotection between the two lower doses; both provide about 2.5 doubling concentration shift. ${ }^{5,36,37}$ With respect to the duration of action of formoterol, a $12 \mu \mathrm{g}$ dose still shows about 1 doubling concentration protection at 8 hours post-dose. There are limited data for the uLABAs. Olodateral (BI1744) at single doses of $2,5,10$, and $20 \mu \mathrm{g}$, delivered via a soft mist inhaler, provided dose-dependent inhibition of MIB for at least 32 hours in the range of 2.0 doubling concentrations for the low dose up to 4.2 doubling concentrations for the high dose. ${ }^{38}$ Maximal protection with each dose was evident 30 minutes post-inhalation. A single dose of $75 \mu \mathrm{g}$ indacaterol was much less impressive. The shift in methacholine $\mathrm{PC}_{20}$ was 1.5 doubling concentrations at 1 hour post-dose and this decreased to 1 doubling concentration on subsequent testing at both 24 and 48 hours. $^{22}$

From these data, a single dose of $200 \mu \mathrm{g}$ salbutamol provides rapid and significant bronchoprotection against MIB that resolves well before 12 hours. As was shown with terbutaline, the effect is most likely gone by 6 hours. The long-acting agent salmeterol shows similar efficacy for inhibiting MIB and the effect is unchanged at 12 hours. At standard doses, the uLABAs olodaterol $(5 \mu \mathrm{g})$ and indacaterol $(75 \mu \mathrm{g})$ provide less protection than LABAs or SABAs. However, high doses of olodaterol provide equipotent bronchoprotection to that seen with salmeterol and salbutamol. The duration of efficacy with uLABAs is on the order of 32-48 hours and this may apply to the LABA agents as well. In contrast to the LAMA mechanism, the LABA/uLABA effect is not a direct result of receptor binding characteristics, as muscarinic receptors are unopposed in the presence of beta agonist; however, the effect may be explained by a prolonged increase in cAMP or decreases in intracellular signaling molecules required for ASM contraction (eg, calcium). An important and welldocumented phenomenon associated with beta agonists is the loss of bronchoprotection following regular use. ${ }^{32,34,35}$ Tolerance develops quickly, is greater with $\mathrm{LABAs}^{34,35}$ than with $\mathrm{SABAs}^{20,24}$ and should be given consideration when interpreting responses to methacholine challenge testing. The LABA data are summarized in Table 4.

Several studies have addressed the effect of beta 2 agonists on other aspects of the methacholine dose-response 
Table 3 Bronchodilator: SABAs

\begin{tabular}{|c|c|c|c|c|c|c|}
\hline Agent & Device & $\begin{array}{l}\text { Dose } \\
(\mu g)\end{array}$ & $\begin{array}{l}\text { End } \\
\text { point }\end{array}$ & $\begin{array}{l}\text { Time } \\
\text { point } \\
\text { (hours) }\end{array}$ & $\begin{array}{l}\text { Dose shift } \\
\text { (doubling } \\
\text { concentrations) }\end{array}$ & Reference (year) \\
\hline Salbutamol & MDI & 200 & $\mathrm{PC}_{20}$ & 1 & 1.9 & Derom et $\mathrm{al}^{27}(1992)$ \\
\hline \multirow[t]{2}{*}{ Salbutamol } & PMDI & 200 & $\mathrm{PC}_{20}$ & 0.5 & 3.5 & Simons et $\mathrm{a}^{26}(1992)$ \\
\hline & & & & 12 & 0 & \\
\hline Salbutamol & pMDI & 200 & $\mathrm{PC}_{20}$ & 0.16 & 4.6 & Parameswaran et $\mathrm{a}^{23}$ (1999) \\
\hline \multirow[t]{3}{*}{ Salbutamol } & pMDI & 100 & $\mathrm{PC}_{20}$ & 0.16 & 2.9 & Parameswaran et $\mathrm{a}^{23}$ (1999) \\
\hline & & 200 & & & 3.9 & \\
\hline & & 400 & & & 4.1 & \\
\hline \multirow[t]{3}{*}{ Salbutamol } & PMDI-HFA & 100 & $\mathrm{PC}_{20}$ & 0.16 & 3.1 & Parameswaran et $\mathrm{a}^{23}(1999)$ \\
\hline & & 200 & & & 3.9 & \\
\hline & & 400 & & & 4.5 & \\
\hline Salbutamol & pMDI & 200 & $\mathrm{PC}_{20}$ & 0.16 & 3.5 & Jokic et al ${ }^{24}(200 \mathrm{I})$ \\
\hline Salbutamol & PMDI & 200 & $\mathrm{PC}_{20}$ & 0.16 & 2.4 & Stewart et $\mathrm{a}^{25}(2012)$ \\
\hline Salbutamol & PMDI & 200 & $\mathrm{PC}_{20}$ & I & 1.9 & Derom et $\mathrm{al}^{27}(1992)$ \\
\hline Salbutamol & Nebulized & 2500 & $\mathrm{PC}_{20}$ & 0.33 & $\sim 3.4$ & Cockcroft ${ }^{28}(1997)$ \\
\hline R-salbutamol & Nebulized & 1250 & $\mathrm{PC}_{20}$ & 0.33 & $\sim 3.3$ & Cockcroft and Swystun ${ }^{28}(1997)$ \\
\hline S-salbutamol & Nebulized & 1250 & $\mathrm{PC}_{20}$ & 0.33 & 0.9 & Cockcroft $^{28}(1997)$ \\
\hline Salbutamol & Nebulized & 2500 & $\mathrm{PC}_{20}$ & 3 & 1.0 & Cockcroft and Swystun ${ }^{28}(1997)$ \\
\hline R-salbutamol & Nebulized & 1250 & $\mathrm{PC}_{20}$ & 3 & 1.2 & Cockcroft and Swystun ${ }^{28}(1997)$ \\
\hline S-salbutamol & Nebulized & 1250 & $\mathrm{PC}_{20}$ & 3 & 0 & Cockcroft and Swystun ${ }^{28}(1997)$ \\
\hline Salbutamol & Nebulized & 200 & $\mathrm{PC}_{20}$ & 0.5 & 2.8 & $\operatorname{Ramsay}^{29}(1999)$ \\
\hline R-salbutamol & Nebulized & 100 & $\mathrm{PC}_{20}$ & 0.5 & 2.9 & Ramsay et a ${ }^{29}(1999)$ \\
\hline S-salbutamol & Nebulized & 100 & $\mathrm{PC}_{20}$ & 0.5 & 0.15 & Ramsay et $\mathrm{al}^{29}$ (1999) \\
\hline Terbutaline & DPI & 500 & $\mathrm{PD}_{20}$ & I & 1.8 & Lipworth et al ${ }^{36}(1998)$ \\
\hline \multirow[t]{3}{*}{ Terbutaline } & Turbuhaler & 250 & $\mathrm{PC}_{20}$ & 1.5 & 1.45 & Derom et a ${ }^{30}(200 \mathrm{I})$ \\
\hline & & & & 3 & 0.5 & \\
\hline & & & & 6 & -0.5 & \\
\hline \multirow[t]{3}{*}{ Terbutaline } & Turbuhaler & 500 & $\mathrm{PC}_{20}$ & 1.5 & 1.67 & Derom et al ${ }^{30}(200 \mathrm{I})$ \\
\hline & & & & 3 & 0.75 & \\
\hline & & & & 6 & 0 & \\
\hline \multirow[t]{3}{*}{ Terbutaline } & pMDI & 250 & $\mathrm{PC}_{20}$ & 1.5 & 0.99 & Derom et al ${ }^{30}(200 \mathrm{I})$ \\
\hline & & & & 3 & 0.13 & \\
\hline & & & & 6 & -0.8 & \\
\hline \multirow[t]{3}{*}{ Terbutaline } & pMDI & 500 & $\mathrm{PC}_{20}$ & 1.5 & 1.54 & Derom et al ${ }^{30}(200 \mathrm{I})$ \\
\hline & & & & 3 & 0.25 & \\
\hline & & & & 6 & 0 & \\
\hline Terbutaline & Turbuhaler & 500 & $\mathrm{PC}_{20}$ & 0.33 & 2.7 & O’Connor et al $\left.\right|^{32}$ (1992) \\
\hline Fenoterol & pMDI & 800 & $\mathrm{PC}_{20}$ & I & 4 & Bandouvakis et al $\left.\right|^{14}(198 \mid)$ \\
\hline
\end{tabular}

Abbreviations: SABAs, short-acting beta agonists; MDI, metered dose inhaler; pMDI, pressurized metered dose inhaler; HFA, hydrofluoroalkane; DPI, dry powder inhaler; $\mathrm{PD}_{20}$, provocation dose that results in a $20 \%$ fall in the forced expiratory volume in I second; $\mathrm{PC}_{20}$, provocation concentration that results in a $20 \%$ fall in the forced expiratory volume in I second.

curve. $^{22,39,40}$ All three studies confirm that beta agonists do not lead to a methacholine dose-response plateau, and that they may actually increase the steepness of the dose-reponse curve (ie, reactivity). ${ }^{39}$

\section{Xanthines}

The use of theophylline as a bronchodilator has largely been replaced by inhaled agents. Nonetheless, as a phosphodiesterase enzyme inhibitor, there is a mechanistic interest surrounding the effect of theophylline on methacholine challenge testing. Oral theophylline administered over 2 months at a median dose of $250 \mathrm{mg}$ /day increases methacholine $\mathrm{PC}_{20}$ by 3.2 fold ${ }^{41}$ Acute effects following intravenous administration of 5,10 , and $15 \mathrm{mg} / \mathrm{L}$ are probably minimal ${ }^{42}$ (Table 5).

\section{Anti-inflammatory and other controller treatments Corticosteroids}

Inhaled corticosteroids (ICS) are the gold standard for decreasing airway inflammation. ICS that are currently in use and for which an effect on MIB has been studied include budesonide, fluticasone, beclomethasone, and ciclesonide. In children, a single $800 \mu \mathrm{g}$ dose of budesonide via pMDI with spacer had no effect on methacholine $\mathrm{PD}_{20} 2$ hours 
Table 4 Bronchodilator: long-acting beta agonists (LABAs)

\begin{tabular}{|c|c|c|c|c|c|c|}
\hline Agent & Device & $\begin{array}{l}\text { Dose } \\
(\mu g)\end{array}$ & End point & $\begin{array}{l}\text { Time point } \\
\text { (hours) }\end{array}$ & $\begin{array}{l}\text { Dose shift } \\
\text { (doubling } \\
\text { concentrations) }\end{array}$ & Reference (year) \\
\hline \multirow[t]{2}{*}{ Salmeterol } & pMDI & 25 & $\mathrm{PC}_{20}$ & 0.5 & $\sim 3$ & Simons et al ${ }^{26}(1992)$ \\
\hline & & & & 12 & $\sim 3$ & \\
\hline \multirow[t]{2}{*}{ Salmeterol } & pMDI & 50 & $\mathrm{PC}_{20}$ & 0.5 & $\sim 4$ & Simons et al ${ }^{26}(1992)$ \\
\hline & & & & 12 & $\sim 4$ & \\
\hline \multirow[t]{2}{*}{ Salmeterol } & pMDI & 50 & $\mathrm{PC}_{20}$ & 1 & 1.9 & Derom et $\mathrm{al}^{27}(1992)$ \\
\hline & & 100 & & & 2.7 & \\
\hline Salmeterol & pMDI & 50 & $\mathrm{PD}_{20}$ & 1 & $\sim 4$ & Verbene et $\mathrm{al}^{33}(1993)$ \\
\hline Salmeterol & pMDI (with chamber) & 50 & $\mathrm{PC}_{20}$ & 1 & 3.3 & Cheung et al ${ }^{34}$ (1992) \\
\hline Salmeterol & pMDI & 50 & $\mathrm{PC}_{20}$ & 1 & 3.3 & Bhagat et al ${ }^{35}(1992)$ \\
\hline \multirow[t]{3}{*}{ Formoterol } & DPI & 6 & $\mathrm{PD}_{20}$ & 1 & 2.5 & Lipworth et al ${ }^{36}$ (1998) \\
\hline & & 12 & & & 2.7 & \\
\hline & & 24 & & & 3.3 & \\
\hline Formoterol & DPI & 12 & $\mathrm{PC}_{20}$ & 0.16 & $\sim 2$ & Davis et al ${ }^{37}(2003)$ \\
\hline \multirow[t]{2}{*}{ Formoterol } & PMDI & 12 & $\mathrm{PC}_{20}$ & 0.5 & 3.8 & Lipworth et al ${ }^{31}(2005)$ \\
\hline & & & & 8 & 1.2 & \\
\hline Formoterol & $\mathrm{DPI}$ & 12 & $\mathrm{PC}_{20}$ & I & 2.6 & Prabhakaran et al ${ }^{5}(201 \mathrm{I})$ \\
\hline Formoterol & DPI & 24 & $\mathrm{PC}_{20}$ & 1 & 3.8 & Prabhakaran et al ${ }^{5}(201 \mathrm{l})$ \\
\hline \multirow[t]{3}{*}{ Indacaterol } & $\mathrm{DPI}$ & 75 & $\mathrm{PC}_{20}$ & 1 & 1.5 & Blais et $\mathrm{a}^{22}(2017)$ \\
\hline & & & & 24 & $\mathrm{I}$ & \\
\hline & & & & 48 & 1 & \\
\hline \multirow[t]{5}{*}{ Olodaterol } & Respimat & 2 & $\mathrm{PC}_{20}$ & 0.5 & 2.1 & O'Byrne et al ${ }^{38}$ (2009) \\
\hline & & & & 4 & 2.0 & \\
\hline & & & & 8 & 1.9 & \\
\hline & & & & 24 & 1.2 & \\
\hline & & & & 32 & 1.2 & \\
\hline \multirow[t]{5}{*}{ Olodaterol } & Respimat & 5 & $\mathrm{PC}_{20}$ & 0.5 & 2.6 & O'Byrne et al ${ }^{38}$ (2009) \\
\hline & & & & 4 & 2.4 & \\
\hline & & & & 8 & 2.5 & \\
\hline & & & & 24 & 1.7 & \\
\hline & & & & 32 & 1.8 & \\
\hline \multirow[t]{5}{*}{ Olodaterol } & Respimat & 10 & $\mathrm{PC}_{20}$ & 0.5 & 3.6 & O'Byrne et $\mathrm{al}^{38}$ \\
\hline & & & & 4 & 3.6 & $(2009)$ \\
\hline & & & & 8 & 3.3 & \\
\hline & & & & 24 & 2.5 & \\
\hline & & & & 32 & 2.1 & \\
\hline \multirow[t]{5}{*}{ Olodaterol } & Respimat & 20 & $\mathrm{PC}_{20}$ & 0.5 & 4.2 & O'Byrne et $\mathrm{al}^{38}$ \\
\hline & & & & 4 & 4.2 & $(2009)$ \\
\hline & & & & 8 & 4.2 & \\
\hline & & & & 24 & 3.0 & \\
\hline & & & & 32 & 2.7 & \\
\hline
\end{tabular}

Abbreviations: $\mathrm{PMDI}$, pressurized metered dose inhaler; $\mathrm{DPI}$, dry powder inhaler; $\mathrm{PD}_{20}$, provocation dose that results in a $20 \%$ fall in the forced expiratory volume in I second; $\mathrm{PC}_{20}$, provocation concentration that results in a $20 \%$ fall in the forced expiratory volume in I second.

post-dose and produced a negligible shift in $\mathrm{PD}_{20}(0.1$ doubling doses) at 5 hours. ${ }^{43} \mathrm{~A}$ shift of 0.79 doubling concentrations in methacholine $\mathrm{PC}_{20}$ occurred following 8 weeks of low-dose budesonide (200 $\mu \mathrm{g} /$ day) ${ }^{44}{ }^{44}$ administering twice the dose for half the time produced a similar effect. ${ }^{45}$ High doses of budesonide ( $1600 \mu \mathrm{g}$ a day for 12 weeks) decrease sensitivity to methacholine by 1.4 doubling concentrations. ${ }^{46}$ High-dose fluticasone ( $500 \mu \mathrm{g} /$ day) via hydrofluoroalkane (HFA) pMDI for 4 weeks or 4 weeks of ciclesonide via HFA
pMDI (400 $\mu \mathrm{g} /$ day) show small changes in airway sensitivity to methacholine ( 0.4 and 0.8 doubling concentration shifts, respectively). ${ }^{47}$ Treatment with ICS over the course of 1 year led to significant improvement in methacholine $\mathrm{PD}_{20}$ (3.7 doubling doses), but the improvement after 3 months was reduced to 1 doubling dose. ${ }^{48}$ Collectively, these data are somewhat equivocal. The variability in response could be due to the level of baseline airway inflammation, which, in asthmatics, influences the level of asthma control and guides the dose 
Table 5 Controllers: inhaled corticosteroid, leukotriene receptor antagonist, theophylline, and ICS/LABA combination therapies

\begin{tabular}{|c|c|c|c|c|c|c|}
\hline \multicolumn{7}{|l|}{ Inhaled corticosteroid } \\
\hline Agent & Device & Dose & End point & Time point & $\begin{array}{l}\text { Dose shift } \\
\text { (doubling } \\
\text { concentrations) }\end{array}$ & Reference (year) \\
\hline Budesonide & DPI & $400 \mu \mathrm{g}$ bid & $\mathrm{PC}_{20}$ & 4 weeks & $\sim 1$ & Bel et al $\left.\right|^{39}(\mid 991)$ \\
\hline $\begin{array}{l}\text { Budesonide } \\
\text { (children) }\end{array}$ & $\begin{array}{l}\text { MDI } \\
\text { (with spacer) }\end{array}$ & $\begin{array}{l}800 \mu g \\
\text { (single dose) }\end{array}$ & $\mathrm{PD}_{20}$ & 5 hours & 0.1 & $\begin{array}{l}\text { Van Essen-Zandvliet et } \mathrm{a}^{43} \\
\text { (1993) }\end{array}$ \\
\hline Budesonide & DPI & $800 \mu g$ bid & $\mathrm{PC}_{20}$ & 12 weeks & $\sim 1.4$ & Booms et al ${ }^{46}(1997)$ \\
\hline Fluticasone & HFA PMDI & $500 \mu g /$ day $\times 4$ weeks & $\mathrm{PC}_{20}$ & $\begin{array}{l}24 \text { hours } \\
\text { post-last dose }\end{array}$ & 2.0 & Lee et $\mathrm{al}^{47}(2004)$ \\
\hline Budesonide & DPI & $200 \mu g /$ day $\times 8$ weeks & $\mathrm{PC}_{20}$ & 8 weeks & 0.79 & Kraan et $\mathrm{al}^{44}(1988)$ \\
\hline $\begin{array}{l}\text { Beclomethasone } \\
\text { diproprionate }\end{array}$ & MDI+spacer & Variable & $\mathrm{PD}_{20}$ & I year & 1.1 & Oga et al ${ }^{48}(200 \mathrm{I})$ \\
\hline Ciclesonide & $\begin{array}{l}\text { HFA } \\
\text { PMDI }\end{array}$ & $400 \mu g /$ day $\times 4$ weeks & $\mathrm{PC}_{20}$ & $\begin{array}{l}24 \text { hours } \\
\text { post-last dose }\end{array}$ & 0.67 & Lee et $\mathrm{al}^{47}(2004)$ \\
\hline \multicolumn{7}{|c|}{ Leukotriene receptor antagonists } \\
\hline Montelukast & Tablet & 20 mg (single dose) & $\mathrm{PC}_{15}$ & 3 hours & $\sim 0$ & Crimi et al $^{51}(2003)$ \\
\hline Montelukast & Tablet & 10 mg (single dose) & $\mathrm{PC}_{20}$ & I hours & $\sim 0.4$ & $\begin{array}{l}\text { Davis and Cockcroft }{ }^{50} \\
(2005)\end{array}$ \\
\hline Pranlukast & Tablet & $225 \mathrm{mg}$ bid $\times$ I week & $\mathrm{PC}_{20}$ & $\begin{array}{l}3-4 \text { hours } \\
\text { post-last dose }\end{array}$ & 0.68 & Fujimura et al $\left.\right|^{52}(1993)$ \\
\hline \multicolumn{7}{|l|}{ Theophylline } \\
\hline Theophylline & IV & $\begin{array}{l}5 \mathrm{mg} / \mathrm{L} \text { (Plasma } \\
\text { concentration) } \\
10 \\
15\end{array}$ & $\mathrm{PC}_{20}$ & I hour & $\begin{array}{l}0.36 \\
0.74 \\
0.61\end{array}$ & Koeter et al ${ }^{42}(1989)$ \\
\hline Theophylline & Tablet & $250 \mathrm{mg} /$ day median dose & $\mathrm{PC}_{20}$ & 2 months & 1.7 & Page et al $(1998)^{41}$ \\
\hline \multicolumn{7}{|c|}{ ICS/LABA combination treatments } \\
\hline Fluticasone + formoterol & pMDI & $125+5$ bid & $\mathrm{PD}_{20}$ & 6 weeks & 3.4 & Cortese et $\mathrm{a}^{59}(2016)$ \\
\hline Fluticasone + formoterol & pMDI & 125 bid +12 prn & $\mathrm{PD}_{20}$ & 6 weeks & 1.8 & Cortese et $\mathrm{a}^{59}(2016)$ \\
\hline Fluticasone + formoterol & pMDI & 250 bid +12 prn & $\mathrm{PD}_{20}$ & 6 weeks & 2.7 & Cortese et $\mathrm{al}^{59}(2016)$ \\
\hline
\end{tabular}

Abbreviations: ICS, inhaled corticosteroids; LABA, long-acting beta agonists; MDI, metered dose inhaler; PMDI, pressurized metered dose inhaler; DPI, dry powder inhaler; HFA, hydrofluoroalkane; bid, twice a day; IV, intravenous; prn, as needed; $\mathrm{PD}_{20}$, provocation dose that results in a $20 \%$ fall in the forced expiratory volume in I second; $\mathrm{PC}_{20}$, provocation concentration that results in a $20 \%$ fall in the forced expiratory volume in I second; $\mathrm{PC}_{15}$, provocation concentration that results in a $15 \%$ fall in the forced expiratory volume in I second.

of ICS. Treatment (non)compliance/(non)adherence may also play a role. Controller data are summarized in Table 5.

A few studies have addressed the effect of regular ICS use on other aspects of the dose-response curve; both budesonide ${ }^{45}$ and fluticasone ${ }^{49}$ result in the appearance or improvement in the plateau response to methacholine.

\section{Leukotriene receptor antagonists}

Leukotriene receptor antagonists (LTRAs) block the effects of cysteinyl leukotrienes, which are potent bronchoconstricting mediators released from inflammatory cells. Antiinflammatory effects have also been proposed. Significant inhibition of ASM contraction to leukotriene stimulation would be expected but as an add-on controller medication in the armamentarium of respiratory treatments, the effect on MIB should be minimal or similar to ICS. Two studies have evaluated the acute effects. One study used a single oral dose of $10 \mathrm{mg}$ and assessed the response at 1 hour post-dose. The other study assessed a single $20 \mathrm{mg}$ dose of oral montelukast at 3 hours. Neither study showed any acute effect of montelukast on MCT outcomes. ${ }^{50,51}$ Pranlukast, given orally for 1 week (550 mg daily dose), produced a similar dose shift to that of ICS ( 0.68 doubling concentration). ${ }^{52}$ LTRA data are summarized in Table 5. Montelukast used regularly appears not to result in a methacholine dose-response plateau. ${ }^{53}$

\section{Antihistamines}

Antihistamines are the standard of care in the treatment of allergic rhinitis. It is not uncommon for those diagnosed 
with allergic rhinitis to also be diagnosed with asthma. Numerous over-the-counter antihistamines are available and examples include diphenhydramine, cetirizine, and desloratadine.

Early concerns regarding the inhibitory effect of antihistamines on bronchoprovocation with nonspecific stimuli were twofold. First, challenges were formerly conducted using histamine and second, early generation antihistamines were not necessarily devoid of anticholinergic properties. There are numerous studies in which many antihistamines have been shown to have little or no effect on MCT and this is independent of dose $\mathrm{e}^{54-58}$ (Table 6).

\section{Combination therapies}

Numerous combination formulations have evolved for the treatment of respiratory disease including SAMA/SABA (eg, IB + salbutamol), ICS/LABA (eg, budesonide + formoterol), and more recently LAMA/uLABA (eg, glycopyrronium + indacaterol). Only two studies relating to the use of combination therapy and MIB could be identified. One investigation used an ICS/LABA combination and the other a LAMA/uLABA combination. The ICS/LABA combination study investigated fluticasone propionate and formoterol fumarate from a single device at a dose of $125 \mu \mathrm{g} / 5 \mu \mathrm{g}$ twice per day for 6 weeks followed by prn formoterol for 4 weeks. This was shown to improve methacholine $\mathrm{PD}_{20}$ by 3.4 doubling doses, although the methodology may be confounding the outcome and the result could be the influence of formoterol alone ${ }^{59}$ (Table 6). The other study used single-dose monotherapies of glycopyrronium $(50 \mu \mathrm{g})$ and indacaterol $(75 \mu \mathrm{g})$ administered together and measured methacholine $\mathrm{PC}_{20}$ at three time points post-dose (1 hour, 24 hours, and 48 hours). At 1 hour, the combination shifted methacholine $\mathrm{PC}_{20}$ by 5 doubling concentrations. At both 24 and 48 hours post-dose, bronchoprotection had decreased to 2 doubling concentrations, and this remained statistically significant (Table 2). ${ }^{22}$

\section{Conclusion}

MCT, although mainly used as a diagnostic aid, has additional clinical applications and various research applications. The varied uses of the MCT warrant the need for understanding the effects of different respiratory medications on the outcome of the test, and this will help guide the appropriate washout periods from treatments that inhibit the response. The bronchodilator treatments that block ASM contraction either by receptor antagonism or functional antagonism are the most potent inhibitors of MIB. Depending on the agent used, the required washout period could be as soon as 6 hours or may require up to 7 days (Table 7). Controller treatments like ICS show varied efficacy, and this is probably a functional modification of the underlying airway inflammation. Combination treatments do not appear to act in an additive or synergistic way, and washout should be consistent with the monotherapy providing the longest duration of efficacy against MIB. Antihistamines do not inhibit the test.

Table 6 Anti-HI histamines

\begin{tabular}{|c|c|c|c|c|c|c|}
\hline Agent & $\begin{array}{l}\text { Route of } \\
\text { administration }\end{array}$ & Dose & $\begin{array}{l}\text { End } \\
\text { point }\end{array}$ & $\begin{array}{l}\text { Time point } \\
\text { (hours) }\end{array}$ & $\begin{array}{l}\text { Dose shift } \\
\text { (doubling } \\
\text { concentrations) }\end{array}$ & Reference (year) \\
\hline Clemastine & Nebulized & $\mathrm{I} \mathrm{mg}$ & sGaw & 0.5 & nsd & Nogradyand Bevan ${ }^{54}(1978)$ \\
\hline Clemastine & Tablet & $\mathrm{l} \mathrm{mg}$ & $\mathrm{PC}_{20}$ & 4 & 0.82 & Wood-Baker and Holgate ${ }^{56}$ (1993) \\
\hline Cetirizine & Tablet & $20 \mathrm{mg}$ & $\mathrm{PC}_{20}$ & 2 weeks & $\sim 0$ & Finnerty et $\mathrm{al}^{55}(1990)$ \\
\hline Cetirizine & Tablet & $10 \mathrm{mg}$ & $\mathrm{PC}_{20}$ & 2 & $\sim 0$ & Cockcroft et al ${ }^{58}(2015)$ \\
\hline Cetirizine & Tablet & $10 \mathrm{mg}$ & $\mathrm{PC}_{20}$ & 2 & 0.26 & Wood-Baker and Holgate ${ }^{56}$ (1993) \\
\hline Diphenhydramine & Tablet & $50 \mathrm{mg}$ & $\mathrm{PC}_{20}$ & 2 & $\sim 0$ & Cockcroft et al ${ }^{58}(2015)$ \\
\hline Brompheniramine & Tablet & $4 \mathrm{mg}$ & $\mathrm{PC}_{20}$ & 4 & 0.59 & Wood-Baker and Holgate ${ }^{56}$ (1993) \\
\hline Loratadine & Tablet & $10 \mathrm{mg} q \mathrm{~d} \times 3$ days & $\mathrm{PC}_{20}$ & 3 & $\sim 0$ & Town and Holgate ${ }^{57}(1990)$ \\
\hline Loratadine & Tablet & $20 \mathrm{mg}$ qd $\times 3$ days & $\mathrm{PC}_{20}$ & 3 & $\sim 0$ & Town and Holgate ${ }^{57}$ (1990) \\
\hline Chlorpheniramine & Inhaled & $5 \mathrm{mg}$ in $3 \mathrm{~mL}$ saline & $\mathrm{PD}_{20}$ & 0.5 & -0.35 & Woenne et $\mathrm{al}^{13}(1978)$ \\
\hline Chlorpheniramine & Tablet & $4 \mathrm{mg}$ & $\mathrm{PC}_{20}$ & 2 & 0.85 & Wood-Baker and Holgate ${ }^{56}$ (1993) \\
\hline Terfenadine & Tablet & $60 \mathrm{mg}$ & $\mathrm{PC}_{20}$ & 2 & 0.09 & Wood-Baker and Holgate ${ }^{56}$ (1993) \\
\hline Cyproheptadine & Tablet & $4 \mathrm{mg}$ & $\mathrm{PC}_{20}$ & 4 & 0.45 & Wood-Baker and Holgate ${ }^{56}$ (1993) \\
\hline Astemizole & Tablet & $10 \mathrm{mg}$ & $\mathrm{PC}_{20}$ & 2 & 0.55 & Wood-Baker and Holgate ${ }^{56}$ (1993) \\
\hline Desloratadine & Tablet & $5 \mathrm{mg}$ & $\mathrm{PC}_{20}$ & 2 & $\sim 0$ & Cockcroft et al ${ }^{58}(2015)$ \\
\hline
\end{tabular}

Abbreviations: $q d$, every day; $\mathrm{PD}_{20}$, provocation dose that results in a $20 \%$ fall in the forced expiratory volume in I second; $\mathrm{PC}_{20}$, $\mathrm{Provocation}$ concentration that results in a $20 \%$ fall in the forced expiratory volume in I second; sGaw, airway conductance; nsd, not significantly different. 
Table 7 Recommended washout intervals prior to MCT

\begin{tabular}{|c|c|c|}
\hline Drug type & Example & $\begin{array}{l}\text { Washout } \\
\text { interval }\end{array}$ \\
\hline \multirow[t]{2}{*}{ Muscarinic antagonists } & SAMA (eg, ipratropium) & 12 hours \\
\hline & LAMA (eg, tiotropium) & 7 days \\
\hline \multirow[t]{3}{*}{ Beta agonists } & SABA (eg, salbutamol) & 6 hours \\
\hline & LABA (eg, salmeterol) & 24 hours \\
\hline & uLABA (eg, olodaterol) & 48 hours \\
\hline Xanthines & Theophylline & Not necessary \\
\hline Inhaled & Single dose & Not necessary \\
\hline \multirow[t]{2}{*}{ glucocorticosteroid } & (eg, budesonide) & \\
\hline & $\begin{array}{l}\text { Stable dose } \\
\text { (eg, budesonide) }\end{array}$ & Unknown \\
\hline \multirow[t]{2}{*}{$\begin{array}{l}\text { Leukotriene receptor } \\
\text { antagonists }\end{array}$} & $\begin{array}{l}\text { Single dose or up to I week } \\
\text { (eg, montelukast) }\end{array}$ & Not necessary \\
\hline & Stable dose & Unknown \\
\hline Antihistamines & $\begin{array}{l}\text { (eg, diphenhydramine, } \\
\text { desloratadine) }\end{array}$ & Not necessary \\
\hline \multirow[t]{3}{*}{$\begin{array}{l}\text { Combination therapies } \\
\text { (limited or no data) }\end{array}$} & $\begin{array}{l}\text { ICS/LABA } \\
\text { (eg, fluticasone/formoterol) }\end{array}$ & 24 hours \\
\hline & $\begin{array}{l}\text { ICS/uLABA } \\
\text { (eg, fluticasone/vilanterol) }\end{array}$ & 48 hours \\
\hline & $\begin{array}{l}\text { LAMA/LABA } \\
\text { (eg, glycopyrronioum/ } \\
\text { indacaterol) }\end{array}$ & 7 days \\
\hline
\end{tabular}

Abbreviations: MCT, methacholine challenge test; SAMA, short-acting muscarinic antagonist; LAMA, long-acting muscarinic antagonist; SABA, short-acting beta agonists; LABA, long-acting beta agonists; uLABA, ultra-long-acting beta agonists; ICS, inhaled corticosteroids.

\section{Disclosure}

The authors report no conflicts of interest in this work.

\section{References}

1. Cockcroft DW. Direct challenge tests: airway hyperresponsiveness in asthma: its measurement and clinical significance. Chest. 2010;138(Suppl 2):18S-24S.

2. Crapo RO, Casaburi R, Coates AL, et al. Guidelines for methacholine and exercise challenge testing-1999. Am J Respir Crit Care Med. 2000;161(1):309-329.

3. Coates AL, Wanger J, Cockcroft DW, Culver BH; Bronchoprovocation Testing Task Force. ERS technical standard on bronchial challenge testing: general considerations and performance of methacholine challenge tests. Eur Respir J. 2017; 1;49(5). pii: 1601526.

4. Woolcock a AJ, Salome CM, Yan K. The shape of the dose-response curve to histamine in asthmatic and normal subjects. Am Rev Respir Dis. 1984;130(1):71-75.

5. Prabhakaran S, Shuster J, Ahrens R, Hendeles L. Methacholine challenge as a clinical bioassay of pulmonary delivery of a long-acting $\beta_{2}$-adrenergic agonist. Pharmacotherapy. 2011;31:449-457.

6. Nair P, Martin JG, Cockcroft DW, et al. Airway hyperresponsiveness in asthma: measurement and clinical relevance. J Allergy Clin Immunol Pract. 2017;5(3):649-659.e2.

7. Herxheimer H. Atropine cigarettes in asthma and emphysema. $\mathrm{Br}$ Med J. 1959;2:167-171.

8. Curry JJ. Comparative action of acetyl-beta-methyl choline and histamine on the respiratory tract in normal, patients with hay fever and subjects with bronchial asthma. J Clin Invest. 1947;26:430-438.

9. Itkin IH. Bronchial hypersensitivity to mecholyl and histamine in asthma subjects. J Allergy Clin Immunol. 1967;40:245-256.
10. Itkin IH, Anand SC. The role of atropine as a mediator blocker of induced bronchial obstruction. J Allergy. 1970;45:178-186.

11. Crimi N, Palermo F, Oliveri R, Polosa R, Settinieri I, Mistretta A. Protective effects of inhaled ipratropium bromide on bronchoconstriction induced by adenosine and methacholine in asthma. Eur Respir J. 1992;5:560-565.

12. Sposato B, Calabrese A, Barzan R, Franco C. Comparison of the protective effect amongst anticholinergic drugs on methacholine-induced bronchoconstriction in asthma. J Asthma. 2008;45:397-401.

13. Woenne R, Kattan M, Orange RP, Levison H. Bronchial hyperreactivity to histamine and methacholine in asthmatic children after inhalation of SCH 1000 and chlorpherniramine maleate. J Allergy Clin Immunol. 1978;62:119-124.

14. Bandouvakis J, Cartier A, Roberts R, Ryan G, Hargreave FE. The effect of ipratropium and fenoterol on methacholine and histamine induced bronchoconstriction. Br J Dis Chest. 1981;75:295-305.

15. Larsson K. Ipratropium bromide: bronchodilator action and effect on methacholine-induced bronchoconstriction. J Asthma. 1987;24: 29-35.

16. Hansel TT, Neighbour H, Erin EM, et al. Glycopyrrolate causes prolonged bronchoprotection and bronchodilatation in patients with asthma. Chest. 2005;128:1974-1979.

17. Sheppard D, Epstein J, Holtzman MJ, Nadel JA, Boushey HA. Effect of route of atropine delivery on bronchospasm from cold air and methacholine. J Appl Physiol. 1983;54:130-133.

18. Illamperuma C, Davis BE, Fenton ME, Cockcroft DW. Duration of bronchoprotection of inhaled ipratropium against inhaled methacholine. Ann Allergy Asthma Immunol. 2009; 102:438-439.

19. Reid JK, Davis BE, Cockcroft DW. The effect of ipratropium nasal spray on bronchial methacholine challenge. Chest. 2005;128:1245-1247.

20. O'Connor BJ, Towse LJ, Barnes PJ. Prolonged effect of tiotropium bromide on methacholine-induced bronchoconstriction in asthma. Am J Respir Crit Care Med. 1996;154:876-880.

21. Blais CM, Davis BE, Cockcroft DW. Duration of bronchoprotection of the long-acting muscarinic antagonists tiotropium \& glycopyrronium against methacholine-induced bronchoconstriction in mild asthmatics. Respir Med. 2016;118:96-101.

22. Blais CM, Davis BE, Cockcroft DW. The effect of glycopyrronium and indacaterol, as monotherapy and in combination, on the methacholine dose-response curve of mild asthmatics: a randomized three-way crossover study. Resp Res. 2017; 18:146.

23. Parameswaran KN, Inman MD, Ekholm BP, et al. Protection against methacholine bronchoconstriction to assess relative potency of inhaled $\beta_{2}$ agonist. Am J Respir Crit Care Med. 1999;160:354-357.

24. Jokic R, Swystun VA, Davis BE, Cockcroft DW. Regular inhaled salbutamol: effect on airway responsiveness to methacholine and AMP and tolerance to bronchoprotection. Chest. 2001;119:370-375.

25. Stewart SL, Martin AL, Davis BE, Cockcroft DW. Salbutamol tolerance to bronchoprotection: course of onset. Ann Allergy Asthma Immunol. 2012;109:454-457.

26. Simons FER, Soni NR, Watson WTA, Becker AB. Bronchodilator and bronchoprotective effects of salmeterol in young patients with asthma. J Allergy Clin Immunol. 1992;90:840-846.

27. Derom EY, Pauwels RA, VanDerStraeten MEF. The effect of inhaled salmeterol on methacholine responsiveness in subjects with asthma up to 12 hours. J Allergy Clin Immunol. 1992;89:811-815.

28. Cockcroft DW, Swystun VA. Effect of single doses of S-salbutamol, R-salbutamol, racemic salbutamol, and placebo on the airway response to methacholine. Thorax. 1997;52:845-848.

29. Ramsay CM, Cowan J, ,Flannery E, McLachlan C, Taylor DR. Bronchoprotective and bronchodilator effects of single doses of (S)-salbutamol, (R)-salbutamol and racemic salbutamol in patients with bronchial asthma. Eur J Clin Pharmacol. 1999;55:353-359.

30. Derom E, Borgstrom L, Schoor JV, Lofroos, Pauwels R. Lung deposition and protective effect of terbutaline delivered from pressurized metered-dose inhalers and the turbuhaler in asthmatic individuals. $\mathrm{Am}$ J Respir Crit Care Med. 2001;164:1398-1402. 
31. Lipworth BJ, Sims EJ, Das SK, Morice AH, O’Connor BJ. Bronchoprotection with formoterol via dry power and metered-dose inhalers in patients with asthma. Ann Allergy Asthma Immunol. 2005;95: 283-290.

32. O'Connor BJ, Aikman SL, Barnes PJ. Tolerance to the nonbronchodilator effects of inhaled $\beta_{2}$ agonists in asthma. NEJM. 1992;327:1204-1208

33. Verbene AAPH, Hop WC, Bos AB, Kerrebijn KF. Effect of a single dose of inhaled salmeterol on baseline airway caliber and methacholine-induced airway obstruction in asthmatic children. J Allergy Clin Immunol. 1993;91:127-134.

34. Cheung D, Timmers MC, Zwinderman AH, Bel EH, Dijkman JH, Sterk PJ. Long-term effects of a long-acting $\beta_{2}$ agonist, salmeterol, on airway hyperresponsiveness in patients with mild asthma. NEJM. 1992;327:1198-1203.

35. Bhagat R, Kalra S, Swystun VA, Cockcroft DW. Rapid onset of tolerance to the bronchoprotective effect of salmeterol. CHEST. 1995;108:1235-1239.

36. Lipworth B, Tan S, Devlin M, Aiken T, Baker R, Hendrick D. Effects of treatment with formoterol on bronchoprotection against methacholine. Am J Med. 1998;104:431-438.

37. Davis BE, Reid JK, Cockcroft DW. Formoterol thrice weekly does not result in the development of tolerance to bronchoprotection. Can Respir J. 2003;10:23-26.

38. O'Byrne PM, van der Linde J, Cockcroft DW, et al. Prolonged bronchoprotection against inhaled methacholine by inhaled BI 1744, a

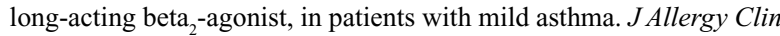
Immunol. 2009;124:1217-1221.

39. Bel EH, Zwinderman AH, Timmers MC, Dijkman JH, Sterk PJ. The protective effect of beta 2 agonist against excessive airway narrowing in response to bronchoconstrictor stimuli in asthma and chronic obstructive lung disease. Thorax 1991;46:9-14.

40. Wong AG, O'Shaughnessy AD, Walker CM, Sears MR. Effects of longacting and short-acting beta-agonists on methacholine dose-response curves in asthmatics. Eur Respir J. 1997;10:330-336

41. Page CP, Cotter T, Kilfeather S, Sullivan P, Spina D, Costello JF. Effect of chronic theophylline treatment on the methacholine dose-response curve in allergic asthmatic subjects. Eur Respir J. 1998;12:24-29.

42. Koeter GH, Kraan J, Boorsma M, Jonkman JHG, Van Der Mark THW. Effect of theophylline and enprofylline on bronchial hyperresponsiveness. Thorax. 1989;44:1022-1026.

43. Van Essen-Zandvliet EEM, Hop WCJ, de Jong H, Ferwerda A, Kerrebijn KF. Minor acute effect of an inhaled corticosteroid (budesonide) on bronchial hyperresponsiveness to methacholine in children with asthma. Eur Respir J. 1993;6:383-386.

44. Kraan J, Koeter GH, Van Der Mark THW, et al. Dosage and time effects of inhaled budesonide on bronchial hyperreactivity. Am Rev Respir Dis. $1988 ; 137: 44-48$
45. Bel EH, Timmers MC, Zwinderman AH, Dijkman JH, Sterk PJ. The effect of inhaled corticosteroids on the maximal degree of airway narrowing to methacholine in asthmatic subjects. Am Rev Respir Dis. 1991;143:109-113.

46. Booms P, Cheung D, Timmers MC, Zwinderman AH, Sterk PJ. Protective effect of inhaled budesonide against unlimited airway narrowing to methacholine in atopic patients with asthma. J Allergy Clin Immunol. 1997;99:330-337.

47. Lee DKC, Haggart K, Currie GP, Bates CE, Lipworth BJ. Effects of hydrofluoroalkane formulations of ciclesonide $400 \mu \mathrm{g}$ once daily vs fluticasone $250 \mu \mathrm{g}$ twice daily on methacholine hyper-responsiveness in mild-to-moderate persistent asthma. Br J Clin Pharm. 2004;58:26-33.

48. Oga T, Nishimura K, Tsukino M, Hajiro T, Ikeda A. Changes in indices of airway hyperresponsiveness during one year of treatment with inhaled corticosteroids in patients with asthma. J Asthma. 2001;38:133-139.

49. Overbeek SE, Rijnbeek PR, Vons C, Mulder PG, Hoogsteden HC, Bogard JM. Effects of fluticasone propionate on methacholine dose-response curves in nonsmoking atopic asthmatics. Eur Respir J. 1996;9:2256-2262.

50. Davis BE, Cockcroft DW. Effect of single dose montelukast on methacholine PC20. Can Respir J. 2005;12:26-28.

51. Crimi N, Pagano C, Palermo F, et al. Inhibitory effect of a leukotriene receptor antagonist (montelukast) on neurokinin A-induced bronchoconstriction. J Allergy Clin Immunol. 2003;111:833-839.

52. Fujimura M, Sakamoto S, Kamio Y, Matsuda T. Effect of a leukotriene antagonist, ONO-1078, on bronchial hyperresponsiveness in patients with asthma. Respir Med. 1993;84:133-138.

53. Ulrik CS, Diamant Z. Effect of montelukast on excessive airway narrowing response to methacholine in adult asthmatics not on controller therapy. Allergy Asthma Proc. 2009;30:64-68.

54. Nogrady SG, Bevan C. Inhaled antihistamines - bronchodilatation and effects on histamine and methacholine induced bronchoconstriction. Thorax. 1978;33:700-704

55. Finnerty JP, Holgate ST, Rihoux JP. The effect of 2 weeks treatment with cetirizine on bronchial reactivity to methacholine in asthma. $\mathrm{Br} J$ Clin Pharmac. 1990;29:29-84.

56. Wood-Baker R, Holgate ST. The comparative actions and adverse effect profile of single doses of $\mathrm{H}_{1}$ - receptor antihistamines in the airways and skin of subjects with asthma. JAllergy Clin Immunol. 1993;91:1005-1014.

57. Town GI, Holgate ST. Comparison of the effect of loratadine on the airway and skin responses to histamine, methacholine, and allergen in subjects with asthma. J Allergy Clin Immunol. 1990;86:886-893.

58. Cockcroft DW, Davis Be, Roh Y, Lourens J. Effect of ingested $\mathrm{H}_{1}$ antihistamines on methacholine challenge. J Allergy Clin Immunol. 2015;135:579-580.

59. Cortese S, Gatta A, Della Valle L, et al. Fluticasone/formoterol association favors long-lasting decrease in bronchial reactivity to methacholine and weekly PEF variability. Int J Immunopathol Pharmacol. 2016;29:769-774.
Journal of Asthma and Allergy

\section{Publish your work in this journal}

The Journal of Asthma and Allergy is an international, peer-reviewed open access journal publishing original research, reports, editorials and commentaries on the following topics: Asthma; Pulmonary physiology; Asthma related clinical health; Clinical immunology and the immunological basis of disease; Pharmacological interventions and new therapies. This journal is included in PubMed. The manuscript management system is completely online and includes a very quick and fair peer-review system, which is all easy to use. Visit http://www. dovepress.com/testimonials.php to read real quotes from published authors. 